\title{
Persistent Insulin Secretion, Assessed by Plasma C-Peptide Estimation in Long-Term Juvenile Diabetics with a Low Insulin Requirement
}

\author{
Ch. Eff, O. Faber ${ }^{1}$, and T. Deckert \\ Steno Memorial Hospital, Gentofte, ${ }^{1}$ Hvidøre Hospital, Klampenborg, Denmark
}

Summary. In order to investigate whether patients with long-standing juvenile diabetes mellitus (onset of diabetes before the age of 30) and a low daily insulin requirement $(<0.50$ units $/ \mathrm{kg}$ body weight $)$ still have functioning B-cells, plasma C-peptide was determined after stimulation (OGTT and glucagon/ tolbutamide) in 64 patients with diabetes of more than 18 years' duration (mean 31 years). Measurable endogenous insulin production was found in $24 \%$ of the patients. The prevalence of severe retinopathy was lower in the secretors than in the non-secretor group. There was no difference in insulin antibody concentration between the two groups. Furthermore, the insulin requirement in the secretor group was relatively constant during the course of diabetes. Metabolic control was similar in both groups. It is concluded that a persisting but low activity of endogenous insulin production can be found in many long-term juvenile diabetics with a low insulin requirement, while others without any residual betacell function develop a low insulin requirement for unknown reasons.

Key words: Insulin-dependent diabetes mellitus, Cpeptide, insulin requirement, insulin antibodies, retinopathy.

A number of insulin-treated diabetic patients with juvenile onset and long duration of disease can be treated with low doses of insulin. In insulin-treated diabetics a correlation between a high degree of residual beta-cell secretory capacity and low insulin requirement has been demonstrated $[7,10]$. The following question was raised: Is a low daily insulin requirement in long-term juvenile diabetics related to residual beta-cell function?
A daily insulin requirement of less than $0.5 \mathrm{U} / \mathrm{kg}$ body weight seems to be associated with longer survival in juvenile diabetics and with better metabolic control [4]. Since residual insulin secretion seems to facilitate good metabolic control, in the short-term at least $[5,7,8]$, the quality of metabolic control as well as late diabetic complications have also been compared in long-standing diabetic patients with and without demonstrable residual beta-cell function.

Insulin antibodies have been shown to be of significance to the duration of the remission period (the period of considerable endogenous insulin production) in juvenile diabetics [3]. It has also been suggested that insulin antibodies may cause beta-cell exhaustion $[3,11]$. In the present group of juvenile long-term diabetics, therefore, the relation of circulating antibodies to residual beta-cell activity was also studied.

\section{Materials and Methods}

The patients were 64 unrelated, consecutive diabetics, 38 female and 26 males, 29 to 74 years of age, with onset of diabetes before the age of 30 , a diabetes duration of more than 18 years and a daily insulin requirement at the time of investigation of 0.5 Units insu$\mathrm{lin} / \mathrm{kg}$ body weight or less. The insulin requirement was defined on clinical grounds as the insulin dose that, over a period of more than 2 months, was necessary to achive well-being and stable bodyweight without severe hypo- or hyperglycaemia. Patients with elevated serum creatinine $(<1.5 \mathrm{mg} / 100 \mathrm{ml})$ were excluded. Two patients were obese ( 127 and $120 \%$ of ideal body weight according to Natvig's table (13)), the others were normal- or underweight. All patients were ambulatory and regularly seen in the Out-patient Clinic, where body weight, postprandial capillary blood glucose concentration, excretion of glucose in the 24-hour urine, and the presence of protein measured with Albustix $\left.{ }^{(}\right)$and ketone bodies measured with Ketostix ${ }^{\circledR}$ in the $24 \mathrm{~h}$ urine were determined at each visit. All had fundus examination through the dilated pupil several times, the latest within 3 months before the study. All but one had been started on insulin treatment within the first 6 months of diagnosis. In this patient, whose diabetes was diagnosed at the age of 6 , insulin treatment was started in 1923 , 
Table 1. Characteristics of C-peptide secretors and non-secretors. Number of cases shown in parenthesis

\begin{tabular}{|c|c|c|c|c|c|c|}
\hline & \multicolumn{2}{|c|}{ C-peptide } & \multicolumn{2}{|c|}{ C-peptide } & \multirow{3}{*}{$\mathbf{P}$} & \multirow{3}{*}{ Test $^{\mathrm{a}}$} \\
\hline & \multicolumn{2}{|c|}{ Secretors $(n=15)$} & \multicolumn{2}{|c|}{ Non-secretors $(n=49)$} & & \\
\hline & Mean & Range & Mean & Range & & \\
\hline Age (years) & 53 & $72-30$ & 50 & $69-29$ & n.s. & 1 \\
\hline$\%$ of ideal body weight & 95 & $78-127$ & 94 & $78-110$ & n.s. & 1 \\
\hline Duration of diabetes mellitus (years) & 32 & $47-18$ & 34 & $54-18$ & n.s. & 1 \\
\hline Age at onset (years) & 21 & $30-11$ & 17 & $29-2$ & $<0.1$ & 1 \\
\hline Insulin requirement (units $/ \mathrm{kg} /$ day) & 0.32 & $0.11-0.45$ & 0.39 & $0.26-0.49$ & $<0.05$ & 1 \\
\hline Blood glucose (mmol/l) & 13.5 & $26.1-5.8$ & 12.7 & $27.3-3.5$ & n.s. & 1 \\
\hline Urine glucose $(\mathrm{g} / 24 \mathrm{~h})$ & 22.5 & $120-0$ & 16.7 & $103-0$ & n.s. & 1 \\
\hline No retinopathy & \multicolumn{2}{|c|}{$47 \%(7)$} & \multicolumn{2}{|c|}{$29 \%(14)\}$} & \multirow{2}{*}{$<0.05$} & 2 \\
\hline Minimal changes & \multicolumn{2}{|c|}{$33 \%(5)$} & $22 \%$ & & & \\
\hline Background retinopathy & \multirow{2}{*}{\multicolumn{2}{|c|}{$\begin{array}{l}13 \%(2) \\
7 \%(1)^{b}\end{array}$}} & \multirow{2}{*}{\multicolumn{2}{|c|}{$29 \%(14)$}} & \multirow{2}{*}{$<0.05$} & 2 \\
\hline Proliferative retinopathy & & & & & & \\
\hline Proteinuria & \multicolumn{2}{|c|}{0} & \multicolumn{2}{|c|}{$10 \%(5)$} & n.s. & 2 \\
\hline Insulin antibodies present & \multicolumn{2}{|c|}{$33 \%(5)$} & \multicolumn{2}{|c|}{$49 \%(23)^{\mathrm{c}}$} & n.s. & 2 \\
\hline $\mathrm{IBC}>50 \mu \mathrm{U} / \mathrm{ml}$ & \multicolumn{2}{|c|}{$27 \%(4)$} & \multicolumn{2}{|c|}{$15 \%(7)$} & 11.5. & 2 \\
\hline
\end{tabular}

a $1=$ Wilcoxon Rank sum test; $2=\mathrm{x}^{2}$ test

b The difference was not significant at the $5 \%$ level

c IBC (insulin binding capacity) was only determined in 62 cases

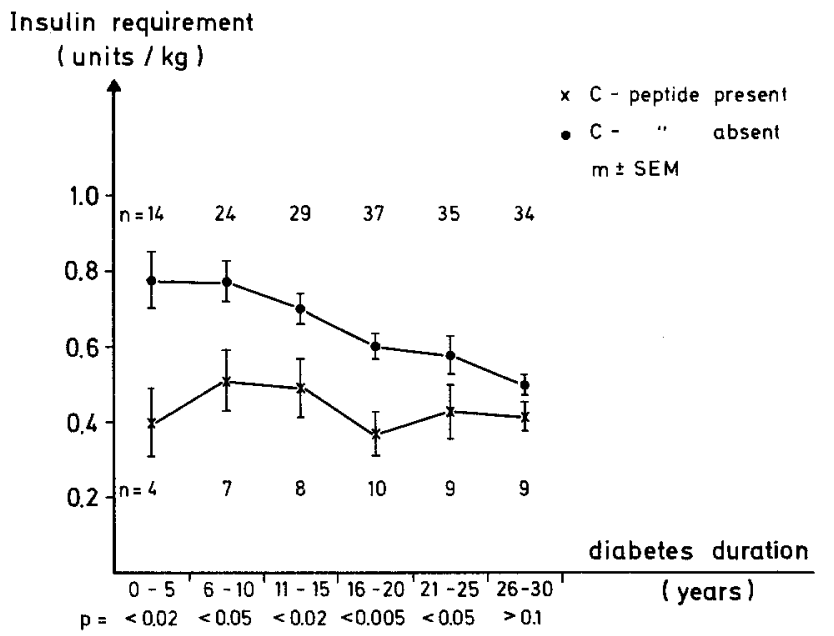

Fig. 1. Daily insulin requirements (Units $/ \mathrm{kg}$ ) in C-peptide secretors $(\mathrm{x})$ and $\mathrm{C}$-peptide non-secretors $(\cdot)$ during the course of diabetes. The same patients were studied sequentially, but data not available in every period. For further explanation, see text

5 years after onset. The patients had been treated with highly purified porcine insulin preparations (Insulin Leo Retard RI ${ }^{\circledR}$, Insulin Leo Neutral $\mathrm{RI}^{\circledR}$ ) for one to two years, $63 \%$ (40 patients) on two injections per day. The patients had been on insulin continuously since diabetes onset, except 2 in whom insulin treatment had been interrupted by a 2 and 5 year period of treatment with oral antidiabetic drugs.

Only in one case had a questionnaire at the time of testing disclosed that one or both parents were diabetic. All patients were thoroughly informed about the investigation and had agreed to participate.

The patients were tested after overnight fasting. Blood was sampled from an antecubital vein, without venestasis, 20 and 0 minutes before oral ingestion of $50 \mathrm{~g}$ glucose in $150 \mathrm{ml}$ of water.

Thirty minutes later a further blood sample was taken and $\mathbf{1} \mathrm{g}$ of tolbutamide was injected IV together with $1 \mathrm{mg}$ glucagon, followed by blood sampling $2,4,6,8,10,20,30$ and 60 minutes after the IV injection. Blood was drawn into glass tubes to which were added 450 Units of Trasylol ${ }^{\circledR}$ and 50 Units of heparin $/ \mathrm{ml}$ blood and stored in ice water until centrifugation. Plasma was stored at $-20^{\circ}$ until analysis which was carried out within two months. The plasma C-peptide immunoreactivity (CPR) was determined, using antiserum M1230 [6] as described by Heding [9]. All samples from each subject were analysed in the same assay. The intraassay coefficient of variation in the low part of the working range of the $\mathrm{C}$ peptide assay was $5.4 \%$ [6]. The effective detection limit of the Cpeptide assay was $0.06 \mathrm{pmol} / \mathrm{ml}$. This limit was defined by the upper range of values measured in 10 pancreatectomized patients. The detection limit in the assay buffer was $0.02 \mathrm{pmol} / \mathrm{ml}$. Consequently, patients with a CPR of $0.06 \mathrm{pmol} / \mathrm{ml}$ or above were considered to have residual beta-cell function and were designated secretors, while those without measurable CPR in the plasma were called non-secretors. A significant increase in CPR was defined as an increase exceeding $16.2 \%$ of the individual fasting level, provided that one of the values was greater than or equal to $0.06 \mathrm{pmol} / \mathrm{ml}$. Insulin antibody was determined in one of the fasting blood samples by the method of Ortved Andersen as insulin binding capacity (IBC) [1]. The IBC in plasma from non-insulintreated patients is $<15 \mu \mathrm{U} / \mathrm{ml}$. Blood glucose concentration was measured by a glucose-oxidase method.

The fundi were classified before the result of the C-peptide determination was known. Minimal changes were defined as 1-3 red spots in one or both eyes, without haemorrhages, exudates or proliferations. Proliferative retinopathy was defined as new vessel formation coming either from the optic disc or from several spots in the periphery. Background retinopathy was defined as retinopathy with more than 3 microaneurysms and haemorrhages or/and exudates, but without proliferations. The quality of metabolic control was determined by the means of the postprandial blood glucose determination one to three hours after breakfast and the 24-hour urinary excretion of glucose during the last 5 visits in the out-patient clinic.

Nephropathy was defined as Albustix ${ }^{\circledR}$ positive proteinuria on more than 5 consecutive occasions.

For statistical analysis of the date the Wilcoxon rank sum test and the $\mathrm{x}^{2}$ test with Yates- correction were used (Table 1). 


\section{Results}

Significant amounts of CPR were demonstrated in the plasma of 15 of the 64 patients $(24 \%)$. The two patients who had been periodically treated with oral antidiabetics were in the secretor group, whereas the patient who had not been started on insulin treatment until 5 years after diabetes onset was in the non-secretor group. A significant increase in CPR was observed in all the secretors after the combined stimulation. The increase in CPR was directly correlated with the fasting CPR ( $\mathrm{r}=0.69, \mathrm{p}<0.005$, Spearman rank correlation test) calculated for secretors only. As shown in Table 1, a lower insulin requirement and a higher prevalence of no or minimal changes at ophthalmoscopy, as well as a lower prevalence of severe retinopathy (background and proliferative), were found in the secretors. There was no difference between the two groups in age at onset, duration of diabetes, body weight, postprandial blood glucose, or 24-h excretion. Six of the secretor group $(40 \%)$ and $34(71 \%)$ of the non-secretor group were on twice daily insulin. Insulin antibodies were not significantly more frequent in the non-secretor group. A high IBC ( $>50 \mu \mathrm{U} / \mathrm{ml})$ was not less common in C-peptide responders than in nonresponders (Table 1). The variation in insulin requirement with increasing duration of diabetes was evaluated from the files of the patient, when obtainable. The results are shown for secretors and nonsecretors separately in Figure 1. For the duration interval 11-15 years for example files on 29 of the 49 non-secretors were available. From these an average insulin requirement of $0.75 \mathrm{U} / \mathrm{kg}$ could be calculated. The other points were calculated in a similar way.

\section{Discussion}

Residual beta-cell function was demonstrated in 24 per cent of our patients with long-term diabetes and low insulin requirement. This should be compared with the results of Hendriksen et al. [10] and Madsbad et al. [12] who found only 2 and 13 secretors out of 27 and 115 insulin-dependent patients with diabetes of more than 18 years' duration, respectively. In these studies the same C-peptide assay was applied. This adds weight to the hypothesis that persistent insulin secretion is associated with a decreased insulin requirement.

The results do however indicate that insulin requirement may also be low in juvenile long term diabetics without any measurable beta-cell function. There was no indication of unusually high physical activity in these patients compared to other long- term diabetics, or of impaired renal function. Rather, the low insulin requirement in these patients seems to be due to high insulin sensitivity or low caloric and/or carbohydrate intake. Although the daily insulin requirement in the non-secretor group was less than $0.5 \mathrm{U} / \mathrm{kg} / \mathrm{day}$, the mean dose was significantly higher than in the secretors. Similar findings have been reported by Hendriksen et al. [10] who observed a lower insulin requirement among insulin-treated diabetics with residual beta-cell function than in diabetics without any demonstrable insulin secretion. In an appreciable number of the patients the daily insulin requirement could be followed from the onset of diabetes (Fig. 1). Mean daily insulin requirement in the group of secretors was constant and low during the entire period, whereas that in non-secretors was considerably and significantly higher in the early years, in accordance with the mean insulin requirement of patients with insulin dependent diabetes $10-15$ years ago [14]. The difference between the groups could not be explained by the use of less purified insulins in the non-secretor group, since all patients were treated with the same insulin preparations.

A low insulin requirement after 10-20 years of diabetes seems to suggest a persisting C-peptide secretion, since only 7 out of 37 non-secretors during this period had an insulin requirement of less than $0.5 \mathrm{U} / \mathrm{kg}$ body weight.

Residual beta-cell function was rarely demonstrated in patients with diabetes onset before the age of 15 ( 3 of 27 patients), more often in patients with onset after the age of 15 (12 of 37). This fits well with the findings of Ludvigsson and Heding [11] who reported a higher frequency of C-peptide secretors in diabetic children with later onset and shorter duration of disease. In a recent study Madsbad et al. [12] demonstrated a lower frequency of secretors in diabetic patients with early onset (age 10-20) than in patients with later onset.

The persistent beta-cell function was not associated with a favourable influence on the metabolic control as evaluated from such crude parameters as the level of postprandial blood glucose or glucose excretion in the urine. This is in contrast to what has been demonstrated in juvenile diabetes of shorter duration $[7,8]$. However, a favourable action of the persistent beta-cell function on the quality of metabolic control can easily be masked by many different factors, for instance food intake and number of daily injections.

It is interesting that persisting beta-cell function appeared to be associated with a decreased incidence of severe diabetic complications, such as proliferative retinopathy, but studies of larger populations are 
needed to substantiate this finding. In a recent study Smith et al. (personal communication) were unable to demonstrate a higher frequency of residual betacell function among patients with long duration of diabetes and no late complications. It cannot be exluded, however, that the higher prevalence of $\mathrm{C}$ peptide secretors among diabetics with onset between 20-30 years of age contributes to the lower relative mortality in this group than in diabetics with onset before the age of 20 [4].

The prevalence of insulin antibodies in these patients was rather low, viz. $45 \%$ as compared to $75 \%$ in patients treated with porcine $\mathrm{NPH}$ insulin preparations in Andersen's study [3]. But it must be remembered that all patients in the present material were treated with highly purified porcine insulin for 1-2 years. High levels of insulin-binding antibodies were demonstrated with similar frequency in both groups of patients. Therefore, circulating insulin antibodies in these amounts do not seem to have any deleterious effect on the beta-cell, as has been suggested $[3,11]$.

It might be questioned whether some of our patients have maturity onset diabetes in the young (MODY) $[15,16]$. This is unlikely, since the prevalence of diabetes in the parents was unusually low $(1.6 \%)$ and the patients were unrelated. Thus, the two patients who could be treated with oral hypoglycaemic agents for lengthy periods, and both of whom were C-peptide secretors, did not belong to the MODY type of diabetes.

\section{References}

1. Andersen, O., Brunfeldt, K., Abildgaard, F.: A method for quantitative determination of insulin antibodies in human plasma. Acta Endocrinol. (Kbh.) 69, 192-208 (1972)

2. Andersen, O.: Insulin antibody formation. 1. The influence of age, sex, infections, insulin dosage and regulation of diabetes. Acta Endocrinol. (Kbh.) 71, 126-140 (1972)
3. Andersen, O.: The immunogenic properties of highly purified insulin preparations. The clinical importance of insulin-binding antibodies. Acta Endocrinol. (Kbh.) 78, 723-735 (1975)

4. Deckert, T., Poulsen, J. E., Larsen, M.: Prognosis of juvenile diabetes mellitus. Diabetologia 14, 363-377 (1978)

5. Enk, B.: Insulin secretion in insulin-requiring diabetics before and during insulin treatment. Acta Endocrinol. (Kbh.) 85, 559-570 (1977)

6. Faber, O. K., Markussen, J., Naithani, V. K., Binder, C.: Production of antisera to synthetic benzyloxicarbonyl-C-peptide of human proinsulin. Hoppe Seylers Z. Physiol. Chem. 357, 751-757 (1976)

7. Faber, O., Binder, C.: B-cell function and blood glucose control in insulin dependent diabetics within the first month of insulin treatment. Diabetologia 13, 263-268 (1977)

8. Grajwer, L. A., Pildes, R. S., Horwitz, D. L., Rubenstein, A. H.: Control of juvenile diabetes mellitus and its relationship to endogenous insulin secretion as measured by C-peptide immunoreactivity. J. Pediatr. 90, 42-48 (1977)

9. Heding, L. G.: Radioimmunological determination of human C-peptide in serum. Diabetologia 11, 541-548 (1975)

10. Hendriksen, C., Faber, O. K., Drejer, J., Binder, C.: Prevalence of residual B-cell function in insulin-treated diabetics evaluated by the plasma C-peptide response to intravenous glucagon. Diabetologia (In press)

11. Ludvigsson, J., Heding, Lise G.: C-peptide in children with juvenile diabetes. Diabetologia 12, 627-630 (1976)

12. Madsbad, S., Faber, O. K., Binder, C., McNair, P., Christiansen, C., Transbøl, I.: Prevalence of residual beta-cell function in insulin-dependent diabetics in relation to age at onset and duration of diabetes. Diabetes (1978) (In press)

13. Natvig, H.: Nye høide-vekttabeller for norske kvinner og menn. Oslo: Landsforeningen for kosthold og helse 1956

14. Poulsen, J. E., Deckert, T.: Insulin preparations and the clinical use of insulin. Acta Med. Scand. [Suppl.] 601, 215 (1976)

15. Tattersall, R. B. Mild familial diabetes with dominant inheritance. Q. J. Med. 43, 339-357 (1974)

16. Tattersall, R.B., Fajans, S.S.: A difference between the inheritance of classical juvenile-onset and maturity-onset type diabetes of young people. Diabetes 24, 44-53 (1975)

Recived: December 28, 1977,

and in revised form: May 24, 1978

T. Deckert

Chief Physician, M. D.

Steno Memorial Hospital

Niels Steensens Vej 2

Dk-2820 Gentofte

Denmark 